\title{
Reduction of Heat Transfer through Walls in Buildings by using Insulation
}

\author{
Hassan Kareem Abdullah \\ Professor of Wasit University \\ Iraq, Wasit Province, University of Wasit
}

\author{
Sajad M. Aboud \\ University of Wasit \\ Iraq, Wasit Province, University of Wasit
}

\begin{abstract}
The present work shows the importance of using thermal insulation for new building walls. To decrease cooling and heating load, so the electric power consumption for airconditioning equipment drop to more than $50 \%$ of that without insulation. The experimental work includes building of two models of (1X1X1)m width, length and height located at (32.5 latitude) kut city, Iraq. The model is set to be each wall faced south, east, north and west direction exactly. The models built from brick. Many type of insulation material were tested \& compared with normal brick wall; polyurethane, polystyrene and composite of newspaper waste mixed with cement mortar (NC). The heat gain was calculated for all the above insulations compared with brick model. The results showed that the maximum percent of energy saving was for polyurethane $61.76 \%$ and the others as follow: (polystyrene58.82\%, NC 31.42\%) .
\end{abstract}

\section{General Terms}

$\mathrm{Q}^{\mathrm{O}}$ : Heat dissipation rate. (w), A : Area $\left(\mathrm{m}^{2}\right), \mathrm{R}$ : Thermal resistance $\left(\mathrm{m}^{2} .{ }^{\circ} \mathrm{C} / \mathrm{W}\right), \mathrm{T}:$ Time, Temperature $\left(\mathrm{Sec},{ }^{\circ} \mathrm{C}\right), \mathrm{K}$ : Thermal conductivity $\left(\mathrm{W} / \mathrm{m} .{ }^{\circ} \mathrm{C}\right)$,

\section{Keywords}

Thermal insulation, Saving energy by insulation, composite insulation.

\section{INTRODUCTION}

Iraq is located in the sub-tropical region hot and dry, which is dominated by desert climate. Where, the summer lasts for more than seven months. The sun shines during these months for long time (more than a $12 \mathrm{hr} /$ day), and the shadow temperature reaches more than $\left(45^{\circ} \mathrm{C}\right)$ so the external wall of models exposed to thermal waves and its strength proportion to the time [1]. The outside walls and roofs should be protected from radiation of the sun and the changing climatic conditions by an appropriate thermal insulation material. The radiation of sun is more than 780 watts $/ \mathrm{m} 2$ on the horizontal surfaces in the summer season which leads to uncomfortable inside temperature. The cooling and heating equipment are considerably decreases in case of using thermal insulation materials which leads to save the consumption of electrical energy.

According to World Watch Institute Estimations, buildings are responsible for $40 \%$ of the total energy consumption worldwide with a greater percentage in the industrialized and urbanized countries (Graham[2], Oldewurtel et al., [3]). In Iraq, the building sector in Baghdad is responsible for $48 \%$ residential, $29 \%$ industrial, $13 \%$ offices, $6 \%$ commercial and $4 \%$ agricultural of energy consumption (Alsammarae, [4]). Most of the energy consumption in Iraq is for cooling and heating that require a great amount of energy loads as compared to lighting and other uses. Hasan [5] indicated that $69 \%$ of the annual energy use in houses in Baghdad consumes for cooling by $42 \%$ and $26 \%$ goes for heating.

The thermal insulations are materials or composite of materials which used mainly to afford resistance to heat flow. Insulations are heterogeneous materials with low thermal conductivity, and they include air pocket. The purpose of using air is due to low thermal conductivities and availability of it. The optimum thickness of the thermal insulation (polystyrene) is investigated by Jozsef Nyers, et al. [6] who is found that is $9 \mathrm{~cm}$ if the minimum payback period of the investment is 1.98 years and if the heat source used is electric energy with the price of $0,08 \mathrm{eu} / \mathrm{kWh}$. The optimum thickness of insulation for extruded polystyrene studied by Meral Ozel [7], who is found that is for south oriented wall was $5.5 \mathrm{~cm}$ and for west north, and east oriented walls was $6 \mathrm{~cm}$. Implicit finite-difference method were used to determine the yearly cooling loads of building walls for the climatic conditions of Turkey. Value of energy consumption and the cost of insulation material based on 10 years lifetime cost of the building was used to calculate the energy savings, payback periods. Ehssan F. A, Judat A. Y. [8], Investigated "the effect of using insulation on the energy saving in buildings by analyzing the thermal performance of a building which is about $600 \mathrm{~m}^{3}$ sizes. The building is built in three different models. In the first model, walls are built with brick. In the second model, a layer of foam (Polystyrene) of $4 \mathrm{~cm}$ thickness has been used as an insulation layer inside walls and on the roof. In the third model, walls are constructed of two parts separated by an air gap of $8 \mathrm{~cm}$ wide; moreover a secondary roof is added to this model. A Qbasic program is prepared to simulate the required mathematical equations in finite difference method and the weather conditions data of Baghdad city in January, 1994. The results of the simulation showed that the ratios of the saved energy by the second and third models with respect to the first model are $29.96 \%$, and $35.40 \%$ respectively.

\section{THE OBJECTIVES}

Saving energy of the Iraqi buildings by using standard thermal insulation and new thermal insulation.

\section{THEORITICAL EQUATIONS}

The of heat conduction rate is directly proportional to the thermal conductivity, the temperature difference and the area of the wall, on the other hand its inversely proportional to the thickness of the wall. 


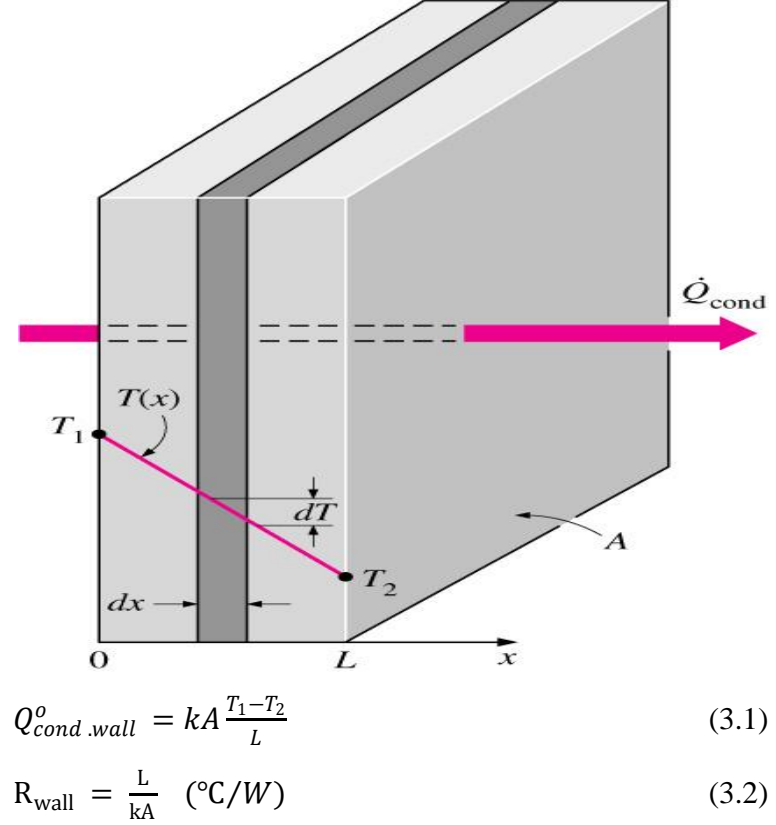

Convection Resistance: Is the surface thermal resistance against heat convection

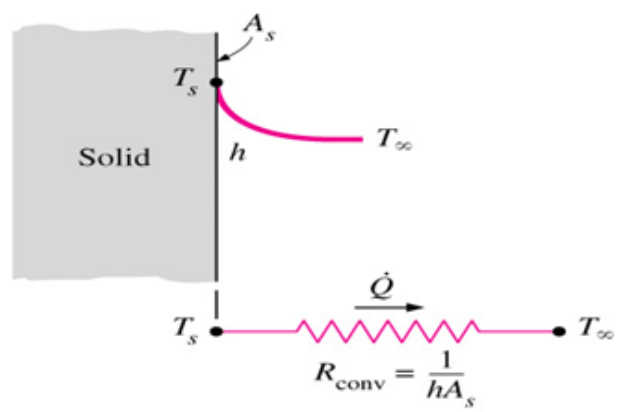

Schematic for convection resistance at a surface

$Q_{\text {conv }}=h A_{s}\left(T_{s}-T_{\infty}\right)$

$\left.\mathrm{R}_{\text {conv }}=\frac{1}{\mathrm{hA}_{\mathrm{s}}}{ }^{\circ} \mathrm{C} / \mathrm{w}\right)$

Radiation Resistance: Is the surface thermal resistance against heat radiation.

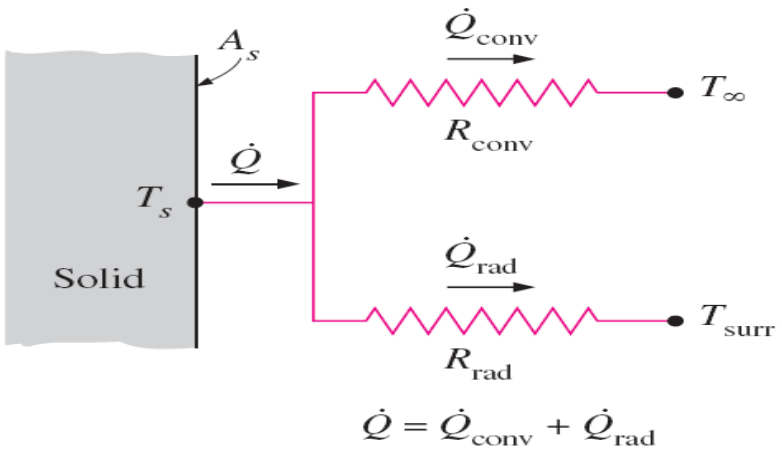

Schematic for convection and radiation resistances at a surface.

$$
\begin{aligned}
Q_{\text {rad }} & =\varepsilon \sigma A_{s}\left(T_{s}^{4}-T_{\text {surr }}^{4}\right)=h_{\text {rad }} A_{s}\left(T_{s}-\mathrm{T}_{\text {surr }}\right) \\
& =\frac{\mathrm{T}_{\mathrm{s}}-\mathrm{T}_{\text {surr }}}{\mathrm{R}_{\text {rad }}} \\
\mathrm{R}_{\text {rad }} & =\frac{1}{\mathrm{~h}_{\text {rad }} \mathrm{A}_{\mathrm{s}}}(\mathrm{K} / \mathrm{W})
\end{aligned}
$$

Rradiation heat transfer coefficient

$$
\begin{aligned}
\mathrm{h}_{\text {rad }}=\frac{\mathrm{Q}_{\text {rad }}}{\mathrm{A}_{\mathrm{s}}\left(\mathrm{T}_{\mathrm{s}}-\mathrm{T}_{\text {surr }}\right)} & =\varepsilon \sigma\left(\mathrm{T}_{\mathrm{s}}^{2}+\mathrm{T}_{\text {surr }}^{2}\right)\left(\mathrm{T}_{\mathrm{s}}\right. \\
& \left.+\mathrm{T}_{\text {surr }}\right)\left(\mathrm{W} / \mathrm{m}^{2} \cdot \mathrm{k}\right) \ldots(3.6)
\end{aligned}
$$

\section{EXPERIMENTAL APPARATUS}

Experimental apparatus deals with room models, installations of insulations and measurements device

\subsection{Room Models}

Two brick model (fig. $1 \& 2)$ where constructed of $(1 * 1 * 1 \mathrm{~m})$ dimensions, one of them insulated with three type of insulation : polyurethane, polystyrene and $\mathrm{NC}$, and the second model is kept without using insulation in order to compare it with the first model.

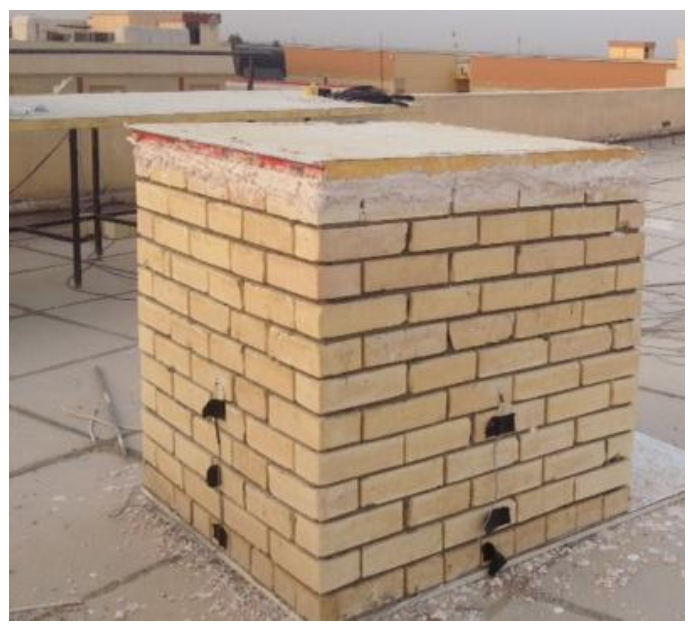

Fig. (1) show the brick model

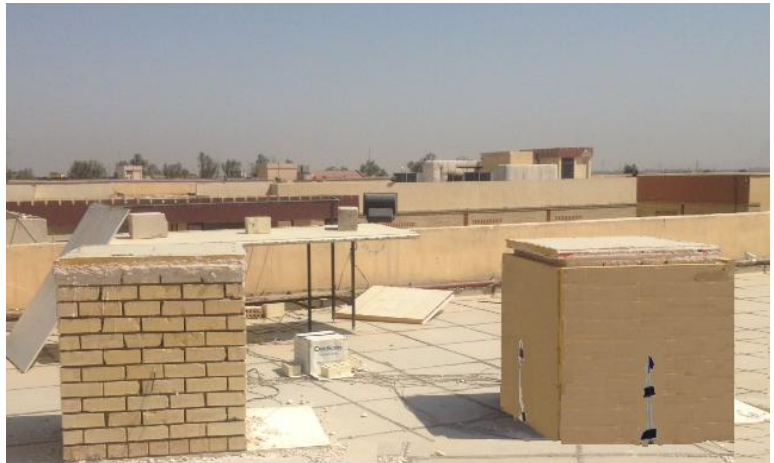

Fig. (2) show the brick \& insulation model.

\subsection{Installations of insulations and Thermocouple}

Thermal insulation is installed on the external wall of the model by using $1 \mathrm{~m}^{2}$ insulation materials with $5 \mathrm{~cm}$ thickness fixed to model by adhesive tape and supporting by rope. The thermocouples distribution was For each model used $11 \mathrm{LM}$ wires have installed to measure the temperature distribution over the model where $8 \mathrm{LM}$ wires are installed in the two side of the walls(each side has $4 \mathrm{LM}$ wires) of the model besides one LM wire in the center as well as two LM in both sides of the roof of the model. As insulation is attached to the model more 4 LM installed in outer surface.

\subsection{A measurement device}

Two devices are used in this study for measuring the parameters where Data logger device type lapjack U3 is used 
for measuring the temperature of the model. And an extension is used to increase the number of measuring point, while Solar power meter device type TES-1333/1333R is used for measuring the solar power during each day of experiment by put it on horizontal surface, then read the value directly on the models, the measuring unit $\mathrm{w} / \mathrm{m}^{2}$ is adjusting in this study.

\section{RESULT AND DISCUSSIONS}

The Fig1: The south \& west walls temperature gradients, at inside $\left(S_{i}, W_{i}\right) \&$ outside of $\left(S_{o}, W_{o}\right)$ for Polystyrene insulation model and for brick model in the same day. Figure (B) for brick model, , shows the temperature between inside \& outside surface of both walls (south \& west), where starting increase during the day time up to a maximum value at a certain time, then decrease in low value at evening. For south wall at 6 a.m. the value of $\mathrm{t}_{\mathrm{So}}-\mathrm{t}_{\mathrm{Si}}$ about $1.3^{\circ} \mathrm{C}$, then increased to maximum value $15^{\circ} \mathrm{C}$ at 2 p.m. again decrease to minimum at $7 \mathrm{p} . \mathrm{m} .1 .4^{\circ} \mathrm{C}$. For west wall at 6 a.m. the value of $\mathrm{t}_{\mathrm{Wo}_{\mathrm{o}}}-\mathrm{t}_{\mathrm{Wi}_{\mathrm{i}}}$ about $1.15^{\circ} \mathrm{C}$, then increased to maximum value $8.9^{\circ} \mathrm{C}$ at 2 p.m. again decrease to minimum at 7 p.m. $1.26^{\circ} \mathrm{C}$. Figure (A) for Polystyrene insulation model, shows the temperature between inside \& outside surface of both walls (south \& west), where starting increase during the day time up to a maximum value at a certain time, then decrease to low value at evening. For south wall at 6 a.m. the value of $t_{\mathrm{So}}-\mathrm{t}_{\mathrm{Si}}$ about $5^{\circ} \mathrm{C}$, then increased to maximum value $17^{\circ} \mathrm{C}$ at 2 p.m. again decrease to minimum at 7 p.m. $8.7^{\circ} \mathrm{C}$. For west wall at 6 a.m. the value of $t_{\mathrm{W}_{0}}-t_{\mathrm{Wi}_{\mathrm{i}}}$ about $4.8^{\circ} \mathrm{C}$, then increased to maximum value $13.8^{\circ} \mathrm{C}$ at 2 p.m. again decrease to minimum at 7 p.m. $8.5^{\circ} \mathrm{C}$. Comparing figure (a) \& (b), it can notice that the maximum difference between inside \& outside was $17^{\circ} \mathrm{C}$ for Polystyrene insulation wall, while for brick at the same time was $15^{\circ} \mathrm{C}$ due to their resistance of brick comparing with Polystyrene insulation, maximum save percent is $11.76 \%$.

The Fig 2: illustrates the south \& west walls temperature gradient, at inside $\left(\mathrm{S}_{\mathrm{i}}, \mathrm{W}_{\mathrm{i}}\right)$ \& outside of $\left(\mathrm{S}_{\mathrm{o}}, \mathrm{W}_{\mathrm{o}}\right)$ for Polyurethane insulation model and for brick model in the same day. Figure (A) for brick model, shows the temperature between inside \& outside surface of both walls (south \& west), where starting increase during the daytime up to a maximum value at a certain time, then decrease in low value at evening. For south wall at 6 a.m. the value of $t_{\mathrm{So}}-t_{\mathrm{Si}}$ about $2.7^{\circ} \mathrm{C}$, then increased to maximum value $8.24^{\circ} \mathrm{C}$ at 2 p.m. again decrease to minimum at 7 p.m. $5^{\circ} \mathrm{C}$. For west wall at 6 a.m. the value of $t_{\mathrm{Wo}}-\mathrm{t}_{\mathrm{Wi}}$ about $2.5^{\circ} \mathrm{C}$, then increased to maximum value $8.15^{\circ} \mathrm{C}$ at 2 p.m. again decrease to minimum at 7 p.m. $4.85^{\circ} \mathrm{C}$. Figure (B) for Polyurethane insulation model, shows the temperature between inside \& outside surface of both walls (south $\&$ west), where starting increase during the day time up to a maximum value at a certain time, then decrease to low value at evening. For south wall at 6 a.m. the value of $t_{\mathrm{So}}-\mathrm{t}_{\mathrm{Si}}$ about $3.95^{\circ} \mathrm{C}$, then increased to maximum value $15.05^{\circ} \mathrm{C}$ at 2 p.m. again decrease to minimum at 7 p.m. $9.33^{\circ}$ C.For west wall at 6 a.m. the value of $t_{\mathrm{Wo}_{0}}-\mathrm{t}_{\mathrm{Wi}}$ about $3.6^{\circ} \mathrm{C}$, then increased to maximum value $14.89^{\circ} \mathrm{C}$ at 2 p.m. again decrease to minimum at 7 p.m. $8.12^{\circ} \mathrm{C}$. Comparing figure (a) \& (b), it can notice that the maximum difference between inside \& outside was $15.05^{\circ} \mathrm{C}$ for Polyurethane insulation wall, while for brick at the same time was $8.24^{\circ} \mathrm{C}$ due to their resistance of brick comparing with Polyurethane insulation, maximum save percent is $45.24 \%$.

The Fig 3: represent the south \& west walls temperature gradient, at inside $\left(\mathrm{S}_{\mathrm{i}}, \mathrm{W}_{\mathrm{i}}\right)$ \& outside of $\left(\mathrm{S}_{\mathrm{o}}, \mathrm{W}_{\mathrm{o}}\right)$ for $(\mathrm{NC})$ insulation model and for brick model in the same day. Figure (A) for brick model, shows the temperature between inside \& outside surface of both walls (south \& west), where starting increase during the day time up to a maximum value at a certain time, then decrease in low value at evening. For south wall at 6 a.m. the value of $\mathrm{t}_{\mathrm{So}}-\mathrm{t}_{\mathrm{Si}}$ about $0.4^{\circ} \mathrm{C}$, then increased to maximum value $8.3^{\circ} \mathrm{C}$ at $2 \mathrm{p} . \mathrm{m}$. again decrease to minimum at 7 p.m. $0.5^{\circ} \mathrm{C}$. For west wall at 6 a.m. the value of $t_{W_{o}}-t_{W}$ about $0.3^{\circ} \mathrm{C}$, then increased to maximum value $7.7^{\circ} \mathrm{C}$ at $2 \mathrm{p} . \mathrm{m}$. again decrease to minimum at 7 p.m. $0.3^{\circ} \mathrm{C}$. Figure (B) for NC model, shows the temperature between inside \& outside surface of both walls (south \& west), where starting increase during the day time up to a maximum value at a certain time, then decrease to low value at evening. For south wall at 6 a.m. the value of $\mathrm{t}_{\mathrm{So}}-\mathrm{t}_{\mathrm{Si}}$ about $0.5^{\circ} \mathrm{C}$, then increased to maximum value $9.9^{\circ} \mathrm{C}$ at 2 p.m. again decrease to minimum at 7 p.m. $0.53^{\circ} \mathrm{C}$.For west wall at 6 a.m. the value of $t_{\mathrm{Wo}_{\mathrm{o}}}-\mathrm{t}_{\mathrm{Wi}}$ about $0.35^{\circ} \mathrm{C}$, then increased to maximum value $9.65^{\circ} \mathrm{C}$ at 2 p.m. again decrease to minimum at 7 p.m. $0.48^{\circ} \mathrm{C}$. Comparing figure (a) \& (b), it can notice that the maximum difference between inside \& outside was $9.9^{\circ} \mathrm{C}$ for (NC) insulation wall, while for brick at the same time was $8.3^{\circ} \mathrm{C}$ due to their resistance of brick comparing with (NC) insulation, maximum save percent is $16.16 \%$.

The Fig 4: shows the temperature variation of outside air temperature comparing with inside air temperature for polyurethane model \& for brick model, the temperature difference between $T_{a}-T_{i}$ increase for starting from morning to maximum value at 2 p.m. the value for brick model was $9{ }^{\circ} \mathrm{C}$,while for polyurethane at the same time the difference reach to $15^{\circ} \mathrm{C}$, that means the insulated wall better than commercial brick wall.

The Fig 5: shows the temperature variation of outside air temperature comparing with inside air temperature for polystyrene model \& for brick model, the temperature difference between $T_{a}-T_{i}$ increase for starting from morning to maximum value at $2 \mathrm{p} . \mathrm{m}$. the value for brick model was $10{ }^{\circ} \mathrm{C}$, while for polystyrene at the same time the difference reach to $12{ }^{\circ} \mathrm{C}$, that means the insulated wall better than commercial brick wall.

The Fig 6: shows the temperature variation of outside air temperature comparing with inside air temperature for NC model \& for brick model, the temperature difference between $\mathrm{T}_{\mathrm{a}}-\mathrm{T}_{\mathrm{i}}$ increase for starting from morning to maximum value at 2 p.m. the value for brick model was $8.5^{\circ} \mathrm{C}$, while for $\mathrm{NC}$ at the same time the difference reach to $9{ }^{\circ} \mathrm{C}$, that means the insulated wall better than commercial brick wall.

The Fig 7: shows that the maximum value of the heat gain in the brick model is $\left(17 \mathrm{watt} / \mathrm{m}^{2}\right)$ at $1 \mathrm{p} . \mathrm{m}$., while the maximum value of the heat gain in the polyurethane insulation model is $\left(6.5 \mathrm{watt} / \mathrm{m}^{2}\right)$ at 2 p.m., the saving energy percent is $61.76 \%$.

The Fig 8: shows that the maximum value of the heat gain in the brick model is $\left(17\right.$ watt $\left./ \mathrm{m}^{2}\right)$ at 2 p.m., while the maximum value of the heat gain in the polystyrene insulation model is $\left(9.2 \mathrm{watt} / \mathrm{m}^{2}\right)$ at 2 p.m., the saving energy percent is $58.82 \%$.

The Fig 9: shows that the maximum value of the heat gain in the brick model is $\left(17.5 \mathrm{watt} / \mathrm{m}^{2}\right)$ at $2 \mathrm{p} . \mathrm{m}$., while the maximum value of the heat gain in the $\mathrm{NC}$ insulation model is $\left(12 \mathrm{watt} / \mathrm{m}^{2}\right)$ at 2 p.m., the saving energy percent is $31.42 \%$.

The Fig 10: depicts the comparison of the solar beam radiation of experimental and numerical results (which get from Ecotect program) which are agreeing well with convergence percentage of $(84 \%)$ 
The Fig 11: depicts the comparison of the solar beam radiation of experimental and numerical results which are agreeing well with convergence percentage of $(82 \%)$

The saving energy of polystyrene of the present study is compared with Ehssan study [8], which deals with $600 \mathrm{~m}^{3}$ and thickness $4 \mathrm{~cm}$. The saving energy of Ehssan is $29 \%$ while the saving energy of present study is $55 \%$. This difference is attributed to the high zone area of Ref[8] which leads to more dissipation of heat rate as well as the smaller insulation thickness retires heat flow lesser than that of present study.

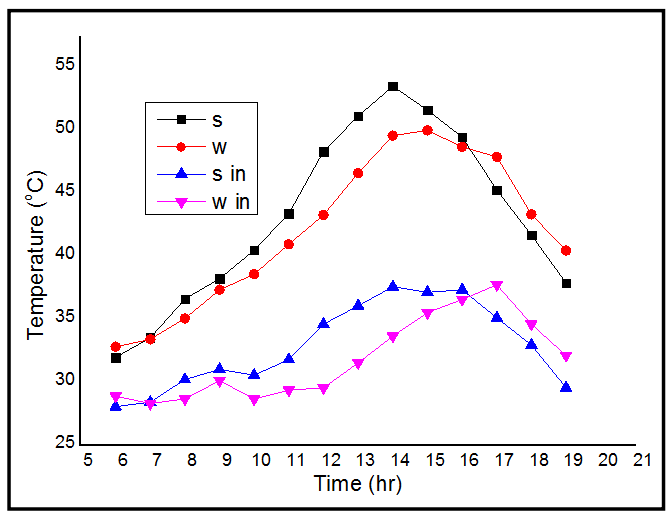

(A) Polystyrene insulation model

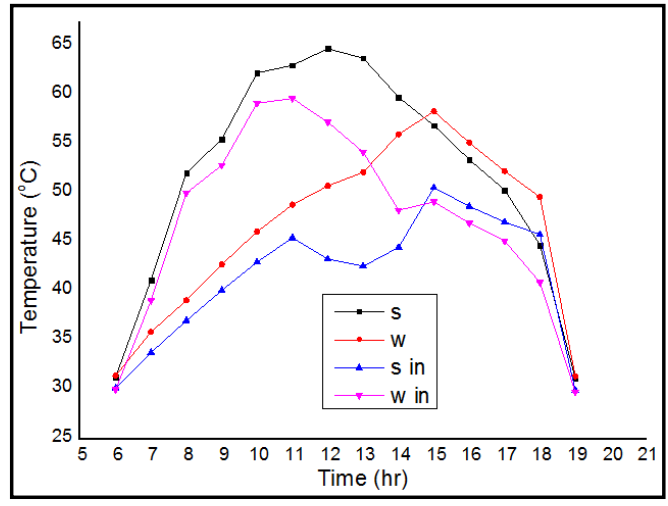

(B)Brick model

Fig 1: show the south and west wall temperature gradient of A\&B model 12 August 2015.

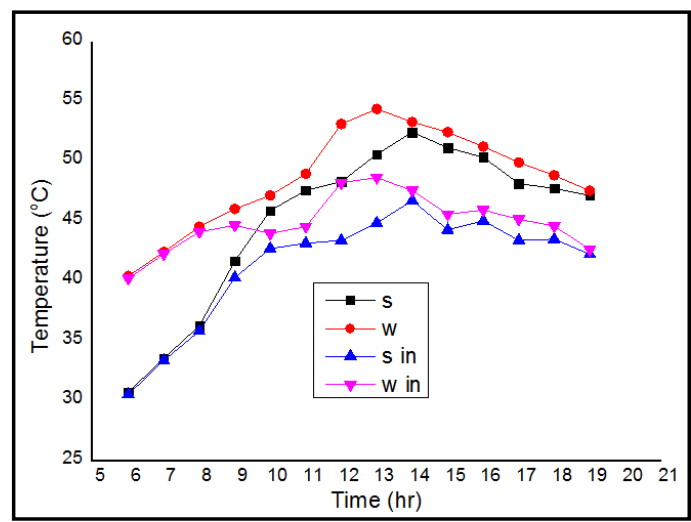

(A)

Brick model

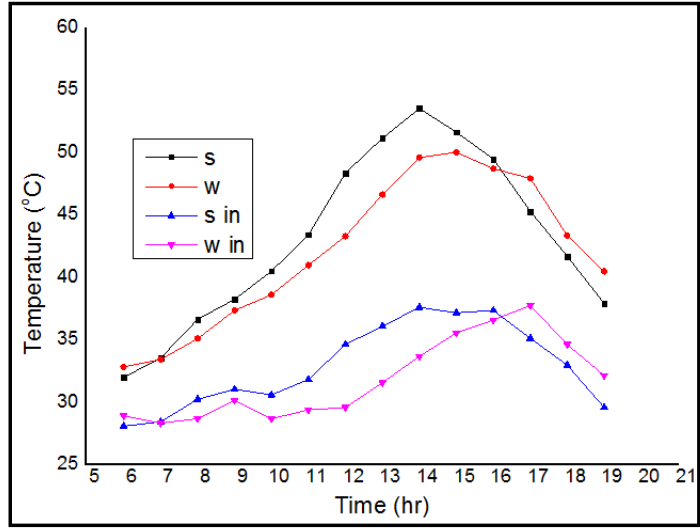

(B) Polyurethane insulation model

Fig 2: show the south and west wall temperature gradient of A\&B model (11 June 2015).

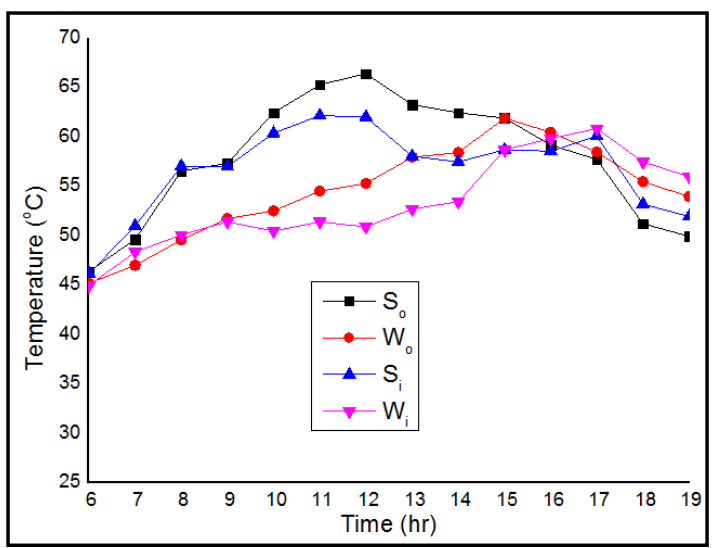

(A) Brick model

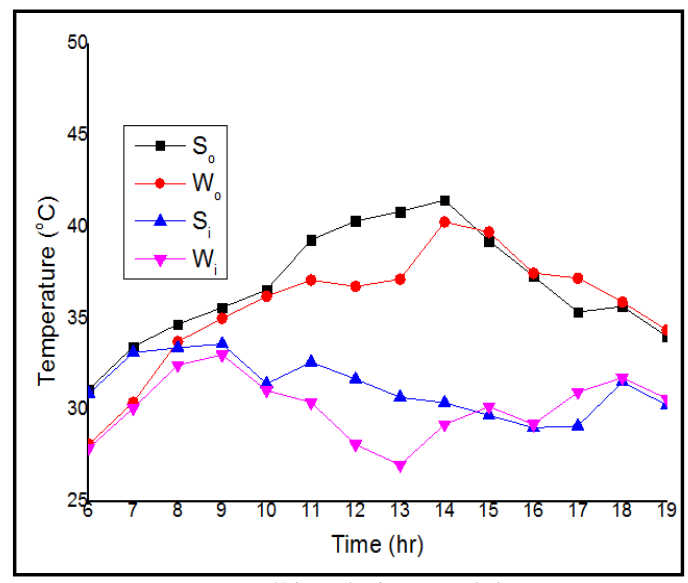

(B) NC insulation model

Fig 3: show the south and west wall temperature gradient of A\&B model. 


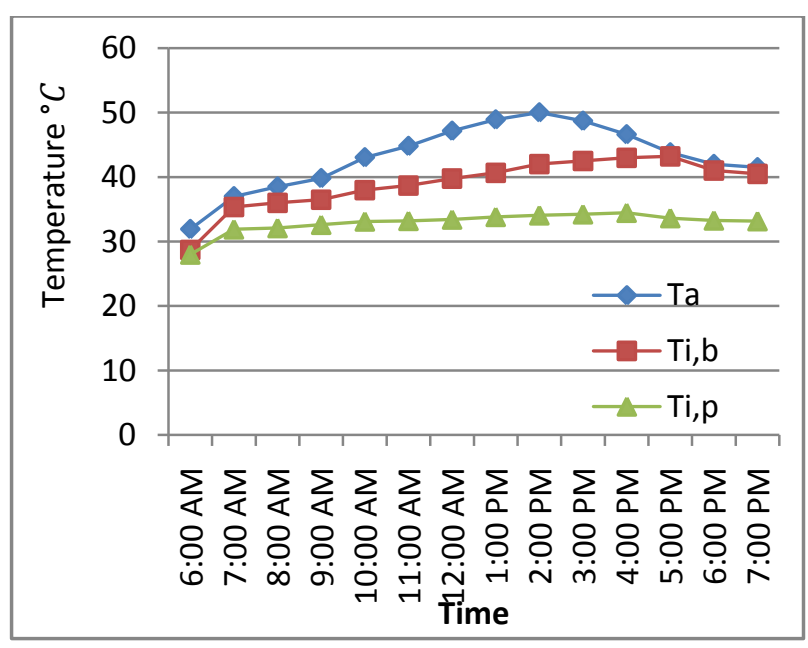

Fig 4: thermal behavior of brick and brick insulated outside by polyurethane model wall.

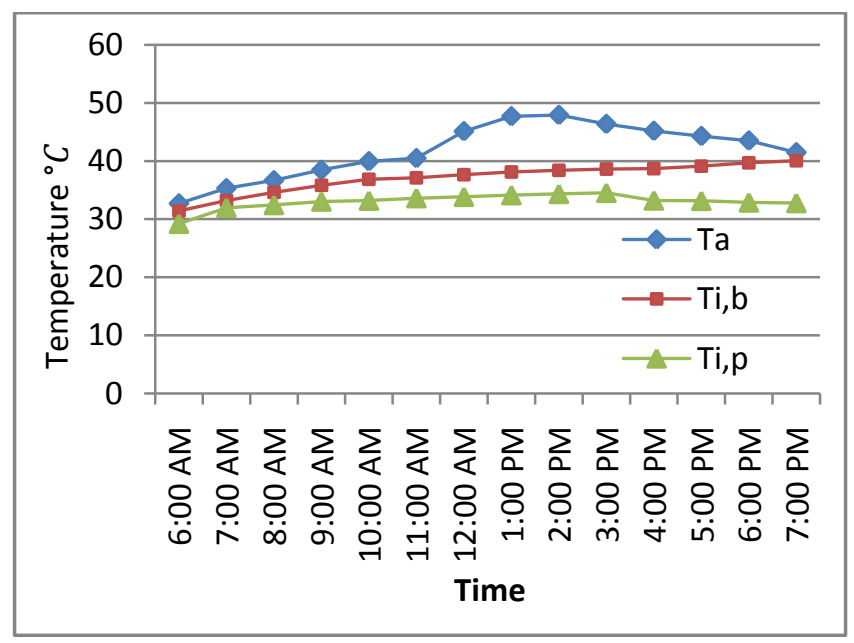

Fig 5: thermal behavior of brick and brick insulated outside by a polystyrene model wall.

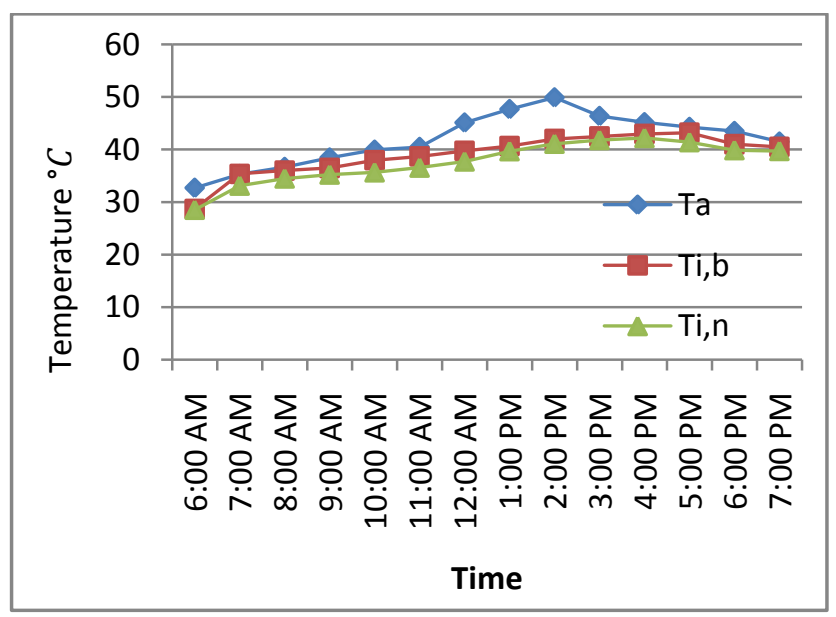

Fig 6: thermal behavior of brick and brick insulated outside by NC model wall.

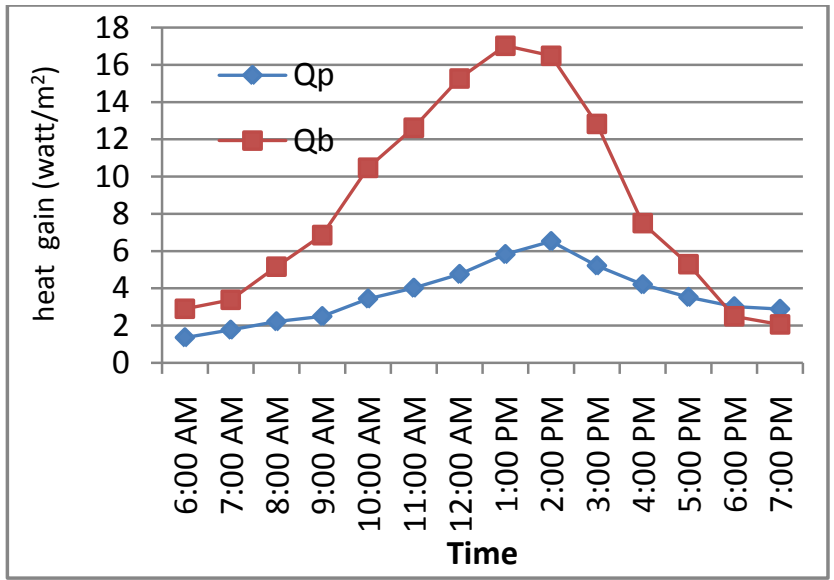

Fig 7: Heat Flux Flow into Internal Surfaces of brick model insulated outside with polyurethane.

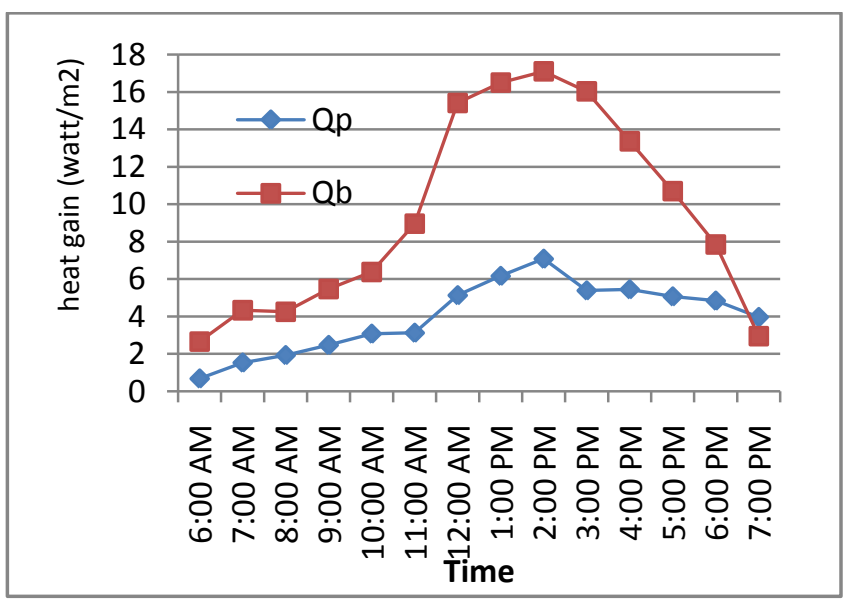

Fig 8: Heat Flux Flow into Internal Surfaces of brick model insulated outside with polystyrene.

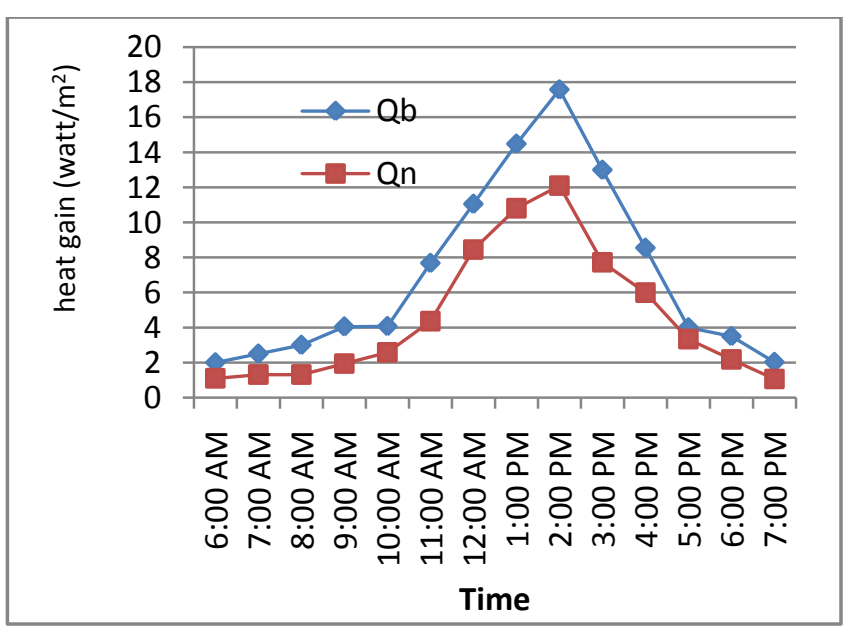

Fig 9: Heat Flux Flow into Internal Surfaces of brick model insulated outside with NC. 


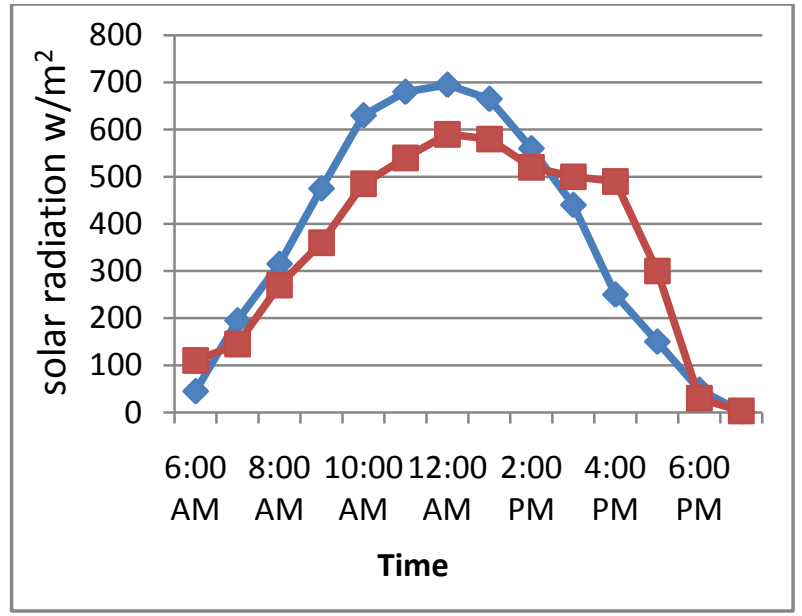

Fig 10: The incident solar radiation on roof of brick model insulated with polyurethane, 13 August 2015.

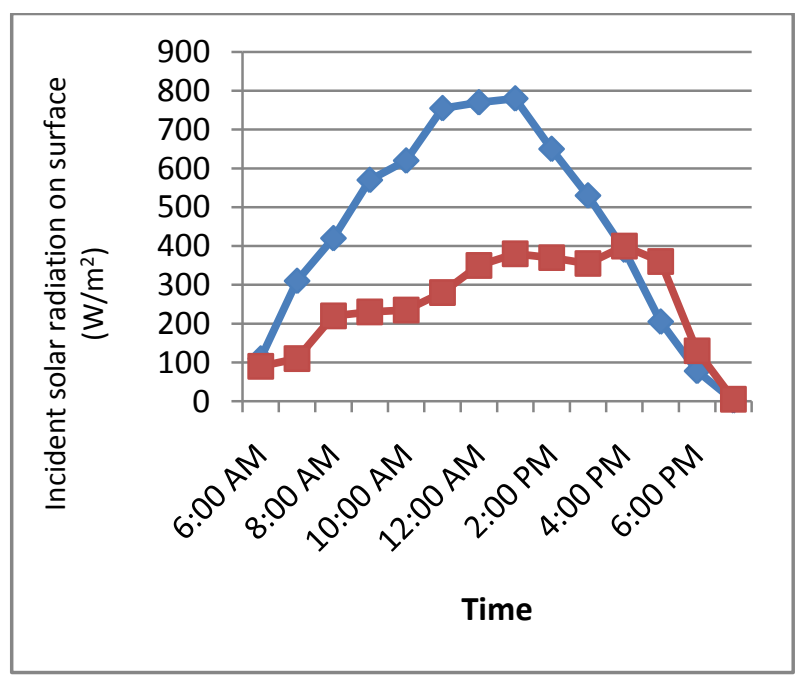

Fig 11: The incident solar radiation on roof of brick model insulated with polystyrene, 12 August 2015.

\section{CONCLUSION}

- The insulated of south and west walls are more effective than that of northern and eastern walls.
- The saving energy for experimentally tested insulation can be arranged from maximum value of saving as follow : $61 . \%$ polyurethane. the others as follow: (polystyrene $58.82 \%, \mathrm{NC} 31.42$ )

\section{ACKNOWLEDGMENTS}

I would like express deepest gratitude to submit my thanks to all members of the ( College Of Engineering / Mechanical Engineering Department at the University Of Wasit )for their cooperation.

\section{REFERENCES}

[1] Alhadithi- Abd Allah (calculating solar radiation on building surfaces )-Report of Research Center buildingIraqi scientific research Council 1975.

[2] Graham, P., 2003. Building Ecology: First Principles for a Sustainable Built Environment. Wiley.Jozsef Nyers " Economic optimum of thermal insulating layer for external wall of brick". Acta Polytechnica Hungarica Vol. 11, No. 7, 2014.

[3] Oldewurtel, F., Parisio, A., Jones, C. N., Morari, M., Gyalistras, D.,Gwerder, M., \& Wirth, K. 2010. Energy efficient building climatecontrol using stochastic model predictive control and weather predictions.In American Control Conference (ACC), IEEE, 2010 (pp. 51005105).

[4] Alsammarae, A., 2005. Electric power 2005. Minister of electricity,Iraq. Available: <http://trade.gov/static/iraq_electricalppt.pdf> [accessed 4,May 2014].

[5] Hasan, A.A., 2012. Available ways for energy conservation in Iraqi residence sector. Alrafidain Univ. Collage Sc. J., 32-50

[6] Jozsef Nyers " Economic optimum of thermal insulating layer for external wall of brick". Acta Polytechnica Hungarica Vol. 11, No. 7, 2014.

[7] Meral Ozel " Effect of wall orientation on the optimum insulation thickness by using a dynamic method" Applied Energy (2011).

[8] Ehssan F. A, Judat A. Y. "The Effect of Using Insulation on the Energy Saving in Building" Tikrit Journal For Engineering Sciences Vol. 71 No. 3 Year 2010. 